\section{B A Institute of \\ YK Business Administration \\ 六下 \\ Karachi \\ Leadership and Ideas for Tomorrow}

Business Review

Volume 10 Issue 1 January - June 2015

$1-1-2015$

\title{
AMO framework and psychological empowerment: Conceptual model decoding the black box between HRM and innovative work behavior
}

\author{
Wali Ur Rehman \\ COMSATS Institute of Information Technology, Islamabad \\ Mansoor Ahmad \\ COMSATS Institute of Information Technology, Islamabad
}

Follow this and additional works at: https://ir.iba.edu.pk/businessreview

Part of the Organizational Behavior and Theory Commons, Performance Management Commons, and the Technology and Innovation Commons

\section{(c) (;)}

This work is licensed under a Creative Commons Attribution 4.0 International License.

\section{Recommended Citation}

Ur Rehman, W., \& Ahmad, M. (2015). AMO framework and psychological empowerment: Conceptual model decoding the black box between HRM and innovative work behavior. Business Review, 10(1), 86-101. Retrieved from https://doi.org/10.54784/1990-6587.1316

This article is brought to you by iRepository for open access under the Creative Commons Attribution 4.0 License and is available at https://ir.iba.edu.pk/businessreview/vol10/iss1/8. For more information, please contact irepository@iba.edu.pk. 


\title{
ARTICLE
}

\section{AMO FRAMEWORK AND PSYCHOLOGICAL EMPOWERMENT: CONCEPTUAL MODEL DECODING THE BLACK BOX BETWEEN HRM AND INNOVATIVE WORK BEHAVIOR}

\author{
Wali ur Rehman \\ COMSATS Institute of Information Technology, Islamabad \\ Mansoor Ahmad \\ COMSATS Institute of Information Technology, Islamabad
}

\begin{abstract}
Firms operate in an environment which is influenced by external forces like, government, professional associations, the competitors and other similar organizations operating in the organizational field (Dimaggio \& Powell, 1983); knowledge intensive firms, are no exceptions. Purpose of this article is to devise comprehensive conceptual and statistical models for opening the black-box between high-involvement HR practices and innovative work behavior of employees working in knowledge intensive companies. The article explains the Ability-Motivation-Opportunity framework as the generating mechanism through which HR practices affect innovative work behavior through psychological empowerment and supportive work environment. Propositions are developed for future research endeavors, in order to substantiate and validate the proposed models.
\end{abstract}

Keywords: high-involvement HR practices, AMO framework, psychological empowerment, supportive work environment, innovative work behavior

\section{Introduction}

Firms operate in an environment which is influenced by external forces like, government, professional associations, the competitors and other similar organizations operating in the organizational field (Dimaggio \& Powell, 1983); knowledge intensive firms, are no exceptions. These forces compel the organization to become similar to each other within an industry through coercive isomorphism, mimetic isomorphism and normative isomorphism (Dimaggio \& Powell, 1983). According to Scott (1995), ostensibly these isomorphism are consequences of the pressures stemming from; government (regulatory authorities), radical changes in external environment (resources deficiency, uncertainty), professionalism (pressures from the professional organizations working in the industry). In addition, organization may also have some motives to become similar to each other and being persuaded by these forces. Scott (1995) further argued that the conforming motives against these forces are; legitimacy, survival, and recognition. According to Khilji (2002), organizations in Pakistan tended to be more passive in terms of adopting management practices from other successful organizations. This tendency of the organizations, according to her, is due to their dependence on the other organizations in the same industry. This article aims at developing a conceptual model where the link of Human resource management with the innovative work behavior is elaborated. Organizations adopt their HR practices in conforming to the institutionalized myths i.e., they implement because other successful organizations in the industry adopted these practices. This tendency may be helpful in the 
aesthetic use but what about the technical use of these human resource practices. This article endeavors to open the black box between the HR practices and one of the important employees' behaviors i.e., the innovative work behavior, which is very important as far as the productivity of the knowledge intensive organizations is concerned.

It is also evident from the two streams of research within Resource Based View (Lowendahl, Revang, \& Fosstenlokken, 2001; Spender, 1996; Tsoukas, 1996). One view emphasizes the stock of knowledge as a potential source of competitive advantage; while the other emphasizes knowledge as a potential source of innovation and value creation (e.g., Leonard \& Sensiper, 1998; Leonard-Barton, 1995). The former view considers the knowledge as being unique and difficult to imitate, substitute or transfer (e.g., Barney, 1991), and emphasizes the superiority of the forms of knowledge which is superior as compared to the competitors' forms of knowledge. While the latter, which is concern of this study, is not considering the stock of knowledge as source of competitive advantage, rather the way it is innovatively employed in the organization in producing new knowledge (in the form of innovative production of the services / goods). Here, the uniqueness and the innovative processes, which are employed by the employees is important. In this regard, employees' innovative behavior is important in order for the organization to remain competitive viz-a-viz competitors, particularly in cases where the stock of knowledge is not unique (Barney, 1991).

There is consensus among management researchers, that different HR practices are designed and implemented in organizations to achieve the end results i.e. productivity of employees, enhanced performance, employees' commitment and loyalty and innovative work behavior of the employees. This study is taking the latter aspect of the employees' behavior, i.e., innovative work behavior. Knowledge intensive firms consider knowledge as a source of competitive advantage, which makes it a vital resource (Barney, 1991).

According to Barney (1991) knowledge intensive firms are also highly dependent on knowledge both as a stock as well as instrumental of competitive advantage. Knowledge intensive companies rely on the knowledge itself as a source of competitive advantage if it is unique and unable to imitate by competitors; however, if it is not unique, then according to Barney (1991) and Spender, (1996) it is instrumental and its creative and innovative utilization give the firm competitive advantage over its competitors. This study considers the latter view and takes the knowledge as instrumental as critical source for the companies. Companies involved in the high-tech industry are required to optimally and innovatively utilize their human resources in order to create new knowledge in the form of the innovative product and services to remain competitive. Employees are required to be innovative in order to produce new products and services, which requires due diligence and care from the management toward their employees (Isabel \& Perez-Santana, 2014). Human resource practices which facilitates, encourage and foster the innovative behavior in employees are inevitable in high-tech companies. Targeted HR practices, which can increase the abilities of the employees, enhance their motivation to become innovative and provide opportunities to apply their knowledge innovatively and produce novel products. The central source of knowledge creation, inter alia, is human resource (Chandler, Keller, \& Lyon, 2000). Firms need to ensure productive use of this resource, which can only be ensured through continuous development of their skills and competences as well as provision of sufficient opportunities to innovate (Bartel, 2004; Harney \& Jordan, 2008).

Recent studies regarding impact of HRM on the performance and behavioral aspects of the employees argued that there is no agreed upon list of HR practices which are considered universal across the firms and countries (Isabel \& Perez-Santana, 2014; Katou \& 
Budhwar, 2010). However, another stream of debate is about the best fit versus best practices (J Paauwe \& Boselie, 2005). Best fit approach demands modification to the practices according to the context of the organization and the environment in which it operates, while best practice approach indicates universalism of the practices, and argue that these practices regardless of the context and environment produce optimal and desired outcomes. According to these researchers a new trend regarding application of AMO framework (AbilityMotivation-Opportunity) to define the HRM is in vogue in the academic researchers. According to Paauwe (2009), AMO framework is indicative of the change mechanism through which the HRM affects performance (e.g., see Bartel, 2004; Harney \& Jordan, 2008). This framework (i.e., AMO) is validated through empirical investigation regarding its role in HRM-Performance relationship (Appelbaum et al., 2000; Delaney \& Huselid, 1996; Subramony, 2009). They also argued that employees perform efficiently when they are capable of doing their job (i.e., they have the required skills and ability), they are provided incentives to do their jobs (increased their motivation to do the job) and provided sufficient opportunities to do the job for which they have skills. According to Boselie (2010) designated and customized HR practices are required to address the aspects related to ability, motivation and opportunity (AMO) of the employees. Such practices, according to him, are termed as high performance work practices (HPWPs). The conforming HR practices are termed as ability-enhancing, motivation-enhancing and opportunity-enhancing HR practices, respectively.

According to Purcell et al., (2003), there are three types of HR practices which are inculcating new skills and increase the ability of the employees, supplemented by the motivational HR practices to motivate the employees to perform optimally, for which sufficient opportunities are to be provided to the employees. According to Delery \& Doty (1996), organizations have two options regarding accumulation of the human resources; one is the buy-orientation, in which organizations induct new skills by carefully selecting employees, implementing rigorous selection and sophisticated recruitment methods (Jiang et al., 2012) to attract and induct employees having desired skills; while the second orientation is the make-orientation, in which the focus is developmental and the desired and requisite skills are imparted in the employees through training and development. Motivation of the employees is increased through provision of incentives as suggested by the social exchange theory (SET) that employees feel accepted by the organization when he is treated fairly (i.e., provided incentives and rewards against his contribution), then they reciprocate towards organization by enhancing their performance and increase their contributions (Blau, 1964). This is due to a psychological bond between the employees and the organizations, which is made stronger through provision of favorable treatment with the employees in terms of the incentives (Haar \& Spell, 2004). According to Jiang et al., (2012), provision of opportunity to the employees increases the confidence of the employees, as they use more discretion and autonomy in performing their task, which can be achieved through flexible work assignment, job rotation, team work, empowerment, involvement, and information sharing. This aspect of the high-involvement practices is comparatively less costly to the other two practices as mentioned above.

According to Farr \& Ford, (1990) innovative work behavior is the intention of the employees to introduce novel and useful ideas regarding processes, procedures, services and products. It is hard to gauge the intentions of employees but organizations can gather the intentions through either formal or informal means. Such intentions of employees are useful in organizational productivity where such innovative and useful ideas can be operationalized and implemented in the organizations. According to Janssen (2000) employees innovative 
work behavior is defined as the innovative ideas put forward by the employees, which could be beneficial for the organizations through their innovative outcomes.

\section{Objectives of the Study}

Objectives of the study are to:

i. Propose a comprehensive conceptual model by opening the black box between high-involvement HR practices and innovative work behavior of employees working in knowledge intensive firms.

ii. Develop propositions for roles of ability-, motivation-, and opportunityenhancing HR practices in predicting innovative work behavior as well as explaining the mediating role of psychological empowerment and moderating role of supportive work environment.

iii. Identify the relevant statistical model for the proposed conceptual model and its estimation.

\section{Significance of the Study}

According to a study conducted by Colquitt \& Zapata-phelan (2007), to assess what constitute theoretical contributions i.e., theory-building research and theory testing research, introduction of a new mediator / moderator of an existing relationship between concepts is also theoretical contribution. They concluded on the basis of sample of 770 articles from Academy of Management Journal. However, according to Pratt (2009), it is important to explain the importance of filling such gap, as mentioned above, which many of the articles published in Academy of Management Journal failed to provide. This shows that researcher's motivation to include the literature to identify the gap is not sufficient; instead justification and importance of filling the identified gap are also required. He further argued that such argument does not intend to undermine the importance of the identification of the research gaps. Such studies, which are conducted to fill the research gap i.e., empirical investigation of the modified relationships also develop existing literature through incremental additions, thereby contributing to the body of knowledge (Pratt, 2009). Such incremental additions to the existing theories constitute theoretical contribution, since the theory is defined by (Bacharach, 1989: p. 496) as:
' a statement of relations among concepts within a boundary set of assumptions and constraints. It is no more than a linguistic device used to organize a complex empirical world . . the purpose of a theoretical statement is twofold: to organize (parsimoniously) and to communicate (clearly)'.

The first objective of the current study is to explore the factors which influence firms to design and implement HR practices (particularly the high-involvement HR practices). Particularly how institutional isomorphism (coercive, mimetic and normative) persuades the organization to adopt certain management patterns (HR practices in this study). Ascertainment of the institutional factors which affect the HR practices is helpful for firms operating in the software industry to take into account while developing HR policies and practices. The study explores whether the institutional theory intact in these industries in order for the firms to get legitimacy and recognition and ensure their survival (implicit motives), as suggested by the institutional isomorphism. 
In addition, the study contributes towards the management research by opening the black-box between the high-involvement HR practices and the innovative work behavior of employees within the firms. As recently, a study conducted on the HR managers put research implications and highlighted the importance of the development of a conceptual model which could consider some intervening variable in the HR practices and innovative behavior relationships particularly for employees involved in the production of the services / goods (Isabel \& Perez-Santana, 2014). Drawing from their study, this study proposes a model of opening the black box between high-involvement HR practices and innovative work behavior through mediating role of psychological empowerment. The current study will add to it by explaining the role of AMO framework in explaining the innovative work behavior through psychological empowerment and the moderating role of supportive work environment. The development of this conceptual model merits contribution of knowledge toward the field of management, particularly in the field of human resource management in knowledge intensive companies, where scant attention is given to the effective management of human resources.

\section{Theoretical Discussion}

\section{Institutional Isomorphism}

Organizational researchers studied and endeavored to explain variation among organizational structures and their behaviors (e.g., Child \& Kieser, 1981; Hannan \& Freeman, 1977; Woodward, 1965). Their major quest was to explore why organizations differ from each other and how they are heterogeneous viz-a-viz each other. Later on, the trend shifted from heterogeneity to homogeneity of organizations and researchers like Dimaggio \& Powell (1983) posed questions of how and why organizations look similar to each other. The deviation from this main stream of research of organizational heterogeneity to organizational homogeneity is appreciated by various researchers. Their point of departure was to seek the explanation for the homogeneity among organizations in terms of their structure, patterns, and practices.

Dimaggio \& Powell (1983) further pointed out the relationship between the life cycle and the organizational homogeneity and posited that in the early phases of the organizational life cycle, organizations tend to be heterogeneous from each other and shows diversity, however, as soon as the life cycle matures, they tend to become similar in form and behavior to other firms. For example, Coser, Kadushin, \& Powell (1982); Tyack (1974); Katz (1975); Barnouw (966) demonstrated shift from diversity at initial stages of the organizational life cycle to homogeneity of the text book publishing, hospital field, public schools and radio industry. Such homogeneity in the forms and behavior as well as structures results in the development of organizational field, where new entrants may be compelled to become homogenous to other organizations of the field.

According to Suddaby, Hardy, \& Nguyen (2011) organizational field constitutes the institutional life where all the actors working in the same industry; and each actor is dependent on other actors in the field. These actors include suppliers, consumers, competitors, other organizations producing similar products, regulatory bodies. This holistic approach towards identification of an industry is useful, since it considers all the actors working within an industry. Organizational field and institutional life, the virtual or physical space the activities carried out therein, either compel or persuade (depending on the nature of the force i.e., pressure or attraction) to follow certain practices in order to become similar to other organizations in the organizational field. 
According to Freeman (1982) organizations start dominating the organizational field when they become older and larger (both in time and in size); hence they do not adjust, instead they lead other organizations as role model. Thereby forcing other smaller or newer organizations to become similar to them in terms of the structures and behaviors, this is threshold for the homogenization. The process of homogenization is best referred to as isomorphism, which according to (Hawley, 1968) is a constraining process which forces or persuades an entity in organizational field to become similar to other entities. These entities to follow and to become similar to others should share same environmental forces as those which are benchmarked.

According to Dimaggio \& Powell (1983: p.149), institutional isomorphism is the 'constraining process that forces one unit in a population to resemble other units that face the same set of institutional conditions'. Organizations tend to become similar to other organizations operating in the same environment. The same environment here refers to the industry (or Organizational field), which shares the same external environment i.e., resources, employees, suppliers, clients and regulatory bodies etc.). The tendency of one unit of the same industry to look like others is termed as institutional isomorphism Dimaggio \& Powell (1983). They further identified three different types of isomorphism with different set of pressures, motives and stakeholders, namely; coercive isomorphism, mimetic isomorphism, and normative isomorphism.

Coercive isomorphism, according to Dimaggio \& Powell (1983), is a kind of similarity among the organizations which is a result of political pressures exerted by the government, regulatory bodies, donor agencies and other powerful organizations in the business environment. The formal pressures exerted by these actors result in coercive isomorphism. These pressures force organizations to adopt patterns disseminated by other influential organizations, upon which formers are dependent. The dependence of the subordinating organizations may range from resource dependence (in case of donor organizations) to concerns for legitimacy (in case of regulatory bodies). There may be some other concerns which persuade them to follow the patterns suggested by the influential organizations. The influence of these dominant organizations is across the industry and all the actors in the field are required to follow these patterns, which consequently result in isomorphism among these organizations.

Mimetic isomorphism is the tendency of organizations to look similar to other organizations as a result of benchmarking (in uncertain situations) other successful organizations. Organizations are working in hyper turbulent environment where uncertainties are inevitable. In such situations, relatively new organizations tend to copy the practices implemented by successful organizations. Such imitations by new organizations result in wide spread implementation of similar practices, which result in mimetic isomorphism. The major concern of the organizations in becoming similar to each other is their survival (copying practices in situations of uncertainties).

Normative isomorphism is the similarity between organizations due to the shared norms and values across the similar professionals. The force which pressurizes these organizations to look similar to each other is the professionalization. By professionalization, they define the conditions and methods of their work to ensure their occupational autonomy. Since organizations, rely on professionals who attended the same formal education systems, invariably look similar as the professional diffuse the same norms and values, which they learnt during their affiliation with formal education centers. Another factor which is also 
important in such isomorphism is the professional networks, with which these professionals are associated. They attend trainings, workshops, learn the norms of the profession and hereby make themselves professionals which increase their chances of readily acceptable for the other similar professional organizations. With their induction in new organizations, these norms and values are penetrated through these new organizations and result in isomorphism. The two driving forces are the legitimation of the cognitive base and the professional associations (Dimaggio \& Powell, 1983).

\section{High-Involvement HR Practices and AMO Framework}

The HR Practices which are considered important for any organization are categorized as high-involvement HR Practices (Isabel \& Perez-Santana, 2014; Lepak, Liao, Chung, \& Harden, 2006; Subramony, 2009; Sun, Aryee, \& Law, 2007). According to Isabel \& Perez-Santana (2014) high-involvement HR practices are increasing the intrinsic motivation of the employees, resultantly increasing the innovative work behavior of the employees, which is driven by the achievement orientation of the employees. These practices are associated with the employee's innovative work behavior. There are three sub-categories of the HR practices namely; ability-enhancing, motivation-enhancing and opportunity enhancing HR practices. This is why AMO framework explains the importance of these HR practices in enhancing the psychological empowerment level of the employees.

According to Isabel \& Perez-Santana (2014), ability enhancing HR practices are meant for either buying skills or enhancing and developing skills of the employees (Cascio, 1991; Flamholtz \& Lacey, 1981). In the former, the staffing is more relevant and organizations develop the system through which they hire highly qualified and skilled employees according to the requirements of the jobs. By doing so, they buy the skills required to perform the requisite tasks. In alternate, training programs are designed to enhance the skills of the existing employees or new incumbents. Sophisticated HR practices are designed and developed for the employees by carefully assessing the training needs of employees and followed by carefully designed training programs to be implemented. At the end of each training program the outcomes are evaluated on the basis of its objectives, whether requisite skills are sufficiently inculcated or need further improvement (Delery \& Doty, 1996; Jiang et al., 2012).

Motivation enhancing HR Practices include compensation and performance appraisals systems of the organization (Isabel \& Perez-Santana, 2014; Jiang et al., 2012). Employees are rewarded for their contribution towards the organizations, which increase their satisfaction and motivation level (Blau, 1964). Performance appraisal also serves as feedback for employees, which give them confidence, if the feedback is in their favor (as results of previous researches suggest that proper and just performance appraisal increases the motivational level of employees) (e.g., Buchner, 2007; Esposito et al., 2013; Meadows \& Pike, 2010).

Opportunity enhancing HR Practices include job design and participation (Isabel \& Perez-Santana, 2014; Jiang et al., 2012; Lepak et al., 2006; Sun et al., 2007). Job design includes all the arrangements by the organization which enhances the experience of the employees. By effective job designs, employees get more opportunities when assigned to different tasks and levels of the jobs. Job design also includes rotation of employees to different tasks and provision of flexible work environment to increase learning and collaboration among employees (Jiang et al., 2012). Employees' participation is involvement 
of employees in decision making process and encouraging their feedback in organizational decisions. Through this practice employees' feedback and suggestions are sought on different organizational issues and are also rewarded for winning suggestions. Besides, employees are kept informed about important decisions, policies and regulations of the organizations, which is also an opportunity-enhancing HR practice.

\section{AMO-Enhancing HR practices and Psychological Empowerment}

Conger \& Kanungo (1988) defined empowerment as motivational aspect of an individual's confidence in his competence. According to Thomas \& Velthouse (1990) this behavioral concept cannot be defined one-dimensionally, rather it is a multi-dimensional concept. They captured this concept by four cognitive dimensions, which an individual perceives about his work. These dimensions are meaning, competence, self-determination and impact. How these dimensions of the psychological empowerment can be affected by ability enhancing, motivation enhancing and opportunity enhancing HR practices is elaborated in the following sections.

Competence is individual's feeling about and confidence in his capabilities and acquired skills to perform his tasks effectively and efficiently. According to Isabel \& PerezSantana (2014), ability enhancing HR practices are meant for either buying skills or enhancing and developing skills of the employees (Cascio, 1991; Flamholtz \& Lacey, 1981). In the former, the staffing is more relevant and organizations develop the system through which they hire highly qualified and skilled employees according to the requirements of the jobs. By doing so, they buy the skills required to perform the requisite tasks. In alternate, training programs are designed to enhance the skills of the existing employees or new incumbents. Sophisticated HR practices are designed and developed for the employees by carefully assessing the training needs of employees and followed by carefully designed training programs to be implemented. At the end of each training program the outcomes are evaluated on the basis of its objectives, whether requisite skills are sufficiently inculcated or need further improvement (Delery \& Doty, 1996; Jiang et al., 2012). This signifies the link between the ability-enhancing HR practices and competence of the employees.

\section{P1: Ability enhancing HR practices increases the confidence of employees' in their competence while performing tasks assigned in an organizations:}

Pla: The sophisticated and careful selection of employees enhances the confidence of the employees inducted through competition.

P1b: The sophisticated and purposeful training programs enhances the competencies of employees.

Meaning is defined as the value of the role, task and job, which an individual judges in comparison with his own standards and ideals (Thomas \& Velthouse, 1990). Motivation enhancing HR Practices include compensation and performance appraisals systems of the organization (Isabel \& Perez-Santana, 2014; Jiang et al., 2012). Employees are rewarded for their contribution towards the organizations, which increase their satisfaction and motivation level (Blau, 1964). Performance appraisal also serves as feedback for employees, which give them confidence, if the feedback is in their favor (as results of previous researches suggest that proper and just performance appraisal increases the motivational level of employees) (e.g., Buchner, 2007; Esposito et al., 2013; Meadows \& Pike, 2010). This suggests propositions that motivation enhancing HR practices increase the meaning an employee places on his job. 
P2: Motivation enhancing HR practices increase the value of the role and job employees place on their job in comparison to his own standards and ideals:

P2a: The performance based compensation system enhances the value an employee perceives about his role, task and job.

P1b: The feedback oriented performance appraisal system enhances the employees' satisfaction on the value he assigns to his roe, task and job performance.

Impact refers to influencing various organizational outcomes in terms of strategic and operational decisions of the organization, through his input. The more an employee is influential in the organizational processes and procedure, more he is empowered. Selfdetermination is the autonomy and discretion an individual enjoys over his work, i.e., sense of having choice in deciding, initiating and regulating the way he performs his work (Deci, Connell, \& Ryan, 1989).. Opportunity enhancing HR Practices include job design and participation (Isabel \& Perez-Santana, 2014; Jiang et al., 2012; Lepak et al., 2006; Sun et al., 2007). Job design includes all the arrangements by the organization which enhances the experience of the employees. By effective job designs, employees get more opportunities when assigned to different tasks and levels of the jobs. Job design also includes rotation of employees to different tasks and provision of flexible work environment to increase learning and collaboration among employees (Jiang et al., 2012). Employees' participation is involvement of employees in decision making process and encouraging their feedback in organizational decisions. Through this practice employees' feedback and suggestions are sought on different organizational issues and are also rewarded for winning suggestions. Besides, employees are kept informed about important decisions, policies and regulations of the organizations, which is also an opportunity-enhancing HR practice. This suggests that opportunities enhancing HR practices increases the feeling of an employee regarding his impact on various organizational outcomes in terms of strategic and operational decision of the organization.

P3: Opportunity enhancing HR practices increase the feeling of an employees' influence on various organizational decision as well as the autonomy he enjoys in deciding his job performance.

P3a: The increased employees' participation opportunity provided by organization enhances the feeling of an employee regarding his impact on various organizational outcomes.

P3b: The flexible job design enhances the feeling of employee in enjoying autonomy over the way his work is being done by him.

Psychological empowerment increases individual's active participation rather than passive orientation about the way his work is done in an organization. Active orientation means sense of autonomy and competence through which an employee can define and shape his work (Spreitzer, 1995; Thomas \& Velthouse, 1990). According to Spreitzer (1995), psychological empowerment cannot be measured on as a dichotomous variables (i.e., empowered or not empowered), rather it should be measured as a continuous variable from less-empowered to more-empowered. The three groups of the HR practices additively 
enhances the psychological empowerment of the employees, there we posit next proposition as

\section{P4: High-involvement HR practices increases the psychological empowerment level of an employee.}

\section{Psychological Empowerment and Innovative Work Behavior}

According to Isabel \& Perez-Santana, (2014), employees' innovative behavior is attributed to personal as well as contextual characteristics. The contextual factors include human resource practices implemented by organizations, which are devised for developing employees' innovative work behavior. According to Chandler et al., (2000), incentives and rewards systems are effective tools to develop employees' innovative behavior. This assertion is also supported by Hornsby et al., (2002) and Kuratko et al., (2005). Isabel \& Perez-Santana (2014) empirically demonstrated that competence based incentive systems increase the innovative behavior of employees, and identified them as important antecedents of the IWB. According to Shalley et al., (2004), human resource practices focusing on evaluation systems and job design are also important antecedents of the employees innovative work behavior. Through evaluation systems, according to Shalley et al., (2004), employees are apprised about their current standing in the organizations viz-a-viz their contributions. Employees receive feedback about their skills, performance and contributions toward the organizations, which gives them confidence and become more productive. According to Isabel \& Perez-Santana, (2014) job design is an effective tool, through which employees learn skills and knowledge about different functions of the organizations. Job rotation, one of the aspects of the job design, serves as on the job training when employees are allocated to different departments and tasks within an organization.

According to Farr \& Ford (1990), innovative work behavior is the intention of the employees to introduce novel and useful ideas regarding processes, procedures, services and products. It is hard to gauge the intentions of employees but organizations can gather the intentions through either formal or informal means. Such intentions of employees are useful in organizational productivity where such innovative and useful ideas can be operationalized and implemented in the organizations. According to Janssen (2000) employees innovative work behavior is defined as the innovative ideas put forward by the employees, which could be beneficial for the organizations through their innovative outcomes.

According to Jiang et al. (2012), employees are guided, trained and influenced to perform innovatively and increase their creativity. High-involvement HR practices are implemented in organizations to enhance employees' skills, increase their participation in decision making, and motivate them to create value for the organization to achieve competitive advantage. Consequently, employees put discretionary efforts in achieving the targets of the organizations and get rewarded accordingly. According to Kennedy (1995) and Siegall \& Gardner (2000), employee empowerment serves as an effective tool for management to make their employees both productive and effective. They studied public and private service sector organizations, respectively. Service sector organizations benefited more from the employee empowerment as they frequently interact with the customers and positively affect service quality and customer satisfaction (Berman, 1995; Lashley, 1999).

Psychological empowerment is a very important predictor of the employee's innovative work behavior. This is attributed to the competence, meaning, autonomy and impact an employee have on his role and job performance. Competent employees are more confident about their skills and creative initiatives and this when augmented by the self- 
determination, this employee provide novel and useful ideas to the management for implementation and production. According to Isabel \& Perez-Santana (2014), if an employee feels that he has a radical impact on the organizational outcomes through his input and decision making participation, he volunteers in putting forth the innovative ideas for implementation. Meaning is also important in predicting innovative work behavior as understanding and considering one's job meaningful and of value, one may prefer to make it more valuable and meaningful by contributing towards the organization in its productivity and performance. This is done through provision of novel and innovative but useful ideas for the organization.

\section{P5: Psychological empowerment increases the innovative work behavior of the employees in an organization. \\ P5a: An employee's feeling of his impact in an organization increases the chances he increases his impact by providing innovative ideas to the organization. \\ P5b: An employee's positive feeling about the value he puts on his job increases the chances that he makes it more valuable by providing innovative ideas to the organization. \\ P5c: An employee's confidence on his competence increases his innovative work behavior. \\ P5b: An employee's increased self-determination increases his productivity by increasing his innovative work behavior.}

P6: High-involvement HR practices increases the psychological empowerment of the employees, which ultimately increases the innovative work behavior of employees.

\section{Moderating Role Supportive Work Environment}

According to Isabel \& Perez-Santana, (2014), employees perform optimally, when they are provided with the conducive work environment. Previous studies related supportive work environment with the positive behavioral outcomes at individual level i.e., enhanced creativity, productivity, increased organizational commitment, high level satisfaction (Delery \& Doty, 1996; Lepak et al., 2006). According to Parker et. al, (2006) supportive work environment constitutes both the coworker support as well as the management support. These two are considered as specific dimensions of the supportive work environment which, according to Isabel \& Perez-Santana (2014), positively affect the employee's innovative work behavior. As previous research suggests that for the innovative behavior to be a success for an organization, it should be augmented and supported by the management and the co-workers. The former would give support in the form of owning the ideas so developed by the individual employees, while the latter help in the form of brainstorming and encouragement and accommodation while individual employees conceive some novel ideas for his organization (Farr \& Ford, 1990). Therefore, we proposes as:

P7: Supportive work environment moderates the impact of psychological empowerment on the innovative work behavior of the employees:

P7a: Co-worker support moderates the impact of psychological empowerment on the innovative work behavior of the employees. 
P7b: $\quad$ Management support moderates the impact of psychological empowerment on the innovative work behavior of the employees.

\section{The Conceptual Model / Propositions}

The independent variable is the high-involvement HR practices, which are further classified into three sub-categories, i.e, Ability-Enhancing HR practices, MotivationEnhancing HR practices and Opportunity-Enhancing HR practices. Each of the three types of HR practices includes two HR practices i.e., staffing and training are ability-enhancing HR practices; compensation and performance appraisal are motivation-enhancing HR practices; and job design and participation are opportunity-enhancing HR practices.

The conceptual model according to the objectives of the study is provided in the Figure-1 below.

\section{Figure 1: Schematic Model of the Theoretical Framework}

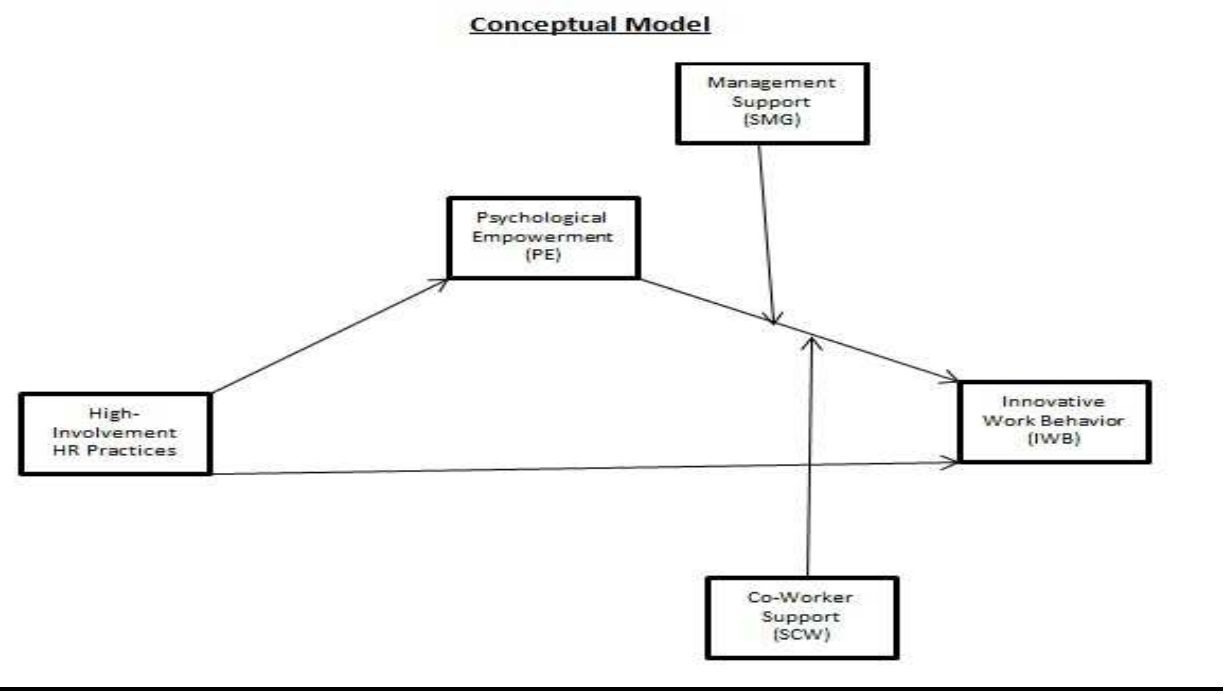

Mathematical representation of the statistical models is as follows:

$$
\begin{aligned}
& \mathrm{PE}=\mathrm{a}_{0}+\mathrm{a}_{1} * \mathrm{HIRP}++\mathrm{e}_{(\mathrm{PE})} \\
& \mathrm{IWB}=\mathrm{b}_{0}+\mathrm{b}_{1} * \mathrm{PE}+\mathrm{b}_{2} * \mathrm{SMG}+\mathrm{b}_{3} * \mathrm{SCW}+\mathrm{b}_{4} * \mathrm{PE} * \mathrm{SMG}+\mathrm{b}_{5} * \mathrm{PE} * \mathrm{SCW}+ \\
& \mathrm{Eq}_{6} \mathrm{HIRP} \mathrm{e}_{(\mathrm{IWB})}
\end{aligned}
$$

Where in Equation (1), PE represents psychological empowerment, which mediates between the HR practices (HRIP) and the dependent variable (IWB); $\mathrm{Eq}(2)$ assesses the moderated impact of HIRP through PE at different values of moderators Management Support (SMG) and Co-Workers Support (SCW). Following Hayes (2013) models for moderation and mediation conceptual model is provided in Figure-1.

\section{Discussion}

The objectives of this research article was to develop a conceptual model for the companies operating in the services industries, particularly where knowledge workers are involved. The propositions proposed in this article were based on the institutional theory that 
the forces operating in the external environment of the organizations force them to adapt their HR practices. These forces are helpful in adoption of the HR practices in these organizations. Merely, adoption of the HR practices as a result of pressures exerted from the external environment, undoubtedly, gives the recognition, legitimacy, but they are useful for their survival or otherwise, should be based on the internal requirements of the firm. These propositions are also based on the performance of the employees working in service industry such as software companies, where employees' knowledge and skills can only be gauged when the product is finished successfully. The HR practices which are considered in this study are High Involvement HR practices, which are focusing on the skills building, performance based incentives, employees' participation and the work design. These HR practices are important as far as they are related to innovative behavior of the employees. The propositions posited in this study may be tested in the service industry to assess the moderating and mediating effects of supportive work environment and psychological empowerment, respectively, on the innovative work behavior of the employees working in the knowledge intisive companies. The AMO framework, which is extensively used and explored by researchers in the field of management sciences, may be trivial as far as the its contribution to the management field is concerned, but it's ability to interpret the relationship between the HR practices and other behavioral aspects of the employees is vital. This study incorporated the psychological empowerment in the model, and their four dimensions correspond to different set of HR practices as proposed in this article. These propositions can be tested through the PROCESS, corresponding model (Hayes, 2013). PROCESS is a syntax which is developed for assessing moderation and mediation models. For different conceptual models, corresponding models' analysis technique is provided in the PROCESS. 蹸

\section{References}

Appelbaum, E., Bailey, T., Berg, P., \& Kalleberg, A. (2000). Manufacturing Advantage: Why High-Performance Work Systems Pay Off. Ithaca, NY: Cornell University Press.

Bacharach, S. B. (1989). Organizational theories: Some criteria for evaluation. Academy of Management Review, 14(1), 496-515.

Barney, J. (1991). Firm resources and sustained competitive advantage. Journal of Management, 17(1), 99-120.

Barnouw, E. (1966). A History of Broadcasting in United States. New York: Oxford University Press.

Bartel, A. P. (2004). Human Resource Management and Organizational Performance: Evidence from retail Banking. Industrial and Labor Relations Review, 57(2), 181-203.

Berman, E. M. (1995). Empowering Employees in State Agencies: A Survey of Recent Progress. International Journal of Public Administration, 18(1), 833-850.

Blau, P. M. (1964). Exchange and Power in Social Life. New Burnswick NJ: Transaction.

Boselie, P. (2010). High Performance Work Practices in the Health Care Sector: A Dutch case study. International Journal of Manpower, 31(1), 42-58.

Buchner, T. W. (2007). Performance management theory $\square$ : A look from the performer' $s$ perspective with implications for HRD Performance Management Theory $\square$ : A Look from the Performer' s Perspective with Implications for HRD. Human Resource Development International, 10(1), 59-73. doi:10.1080/13678860601170294 
Cascio, W. F. (1991). Costing Human Resource: The Financial Impact of Behavior in Organizations. Boston: PWS-Kent. Boston: PWS-Kent.

Chandler, G. N., Keller, C., \& Lyon, D. W. (2000). Unraveling the determinants and consequences of an innovation-supportive organizational culture. Entrepreneurship Theory and Practice, 25(1), 59-76.

Child, J., \& Kieser, A. (1981). Development of Organizations over Time. In C. N. Paul \& H. S. William (Eds.), Handbook of Organizational Design (pp. 28-64). New York: Oxford University Press.

Colquitt, J. A., \& Zapata-phelan, C. P. (2007). Trends in theory building and theory testing: A five-decade study of the Academy of Management Journal. Academy of Management Journal, 50(1), 1261-1303.

Conger, J. A., \& Kanungo, N. R. (1988). Empowerment Process $\square$ : The Theory and Practice Integrating. Academy of Management Review, 13(3), 471-482.

Coser, L., Kadushin, C., \& Powell, W. W. (1982). Books: The Culture and Commerce of Book Publishing. New York: Basic Books.

Deci, E. L., Connell, J. E., \& Ryan, R. M. (1989). Self-Determination in a Work Organization. Journal of Applied Psychology, 74(4), 580-590.

Delaney, J. T., \& Huselid, M. A. (1996). The Impact of Human Resource Management Practices on Performance in for-profit and nonprofit organizations. Academy of Management Journal, 39(4), 949-969.

Delery, J. E., \& Doty, D. H. (1996). Modes of theorizing in strategic human resource management: tests of universalistic, contingency, and configurational performance predictions. Academy of Management Journal, 39(4), 802-835.

Dimaggio, P. J., \& Powell, W. W. (1983). The Iron Cage Revisited: Institutional Isomorphism and Collective Rationality in Organizational Fields. American Sociological Review, 48(2), 147-160.

Esposito, V., Nito, E. De, Giuridiche, S., Sociali, E., Economia, D., \& Silvestri, L. (2013). Dealing with knowledge in the Italian public universities The role of performance management systems. Journal of Intellectual Capital, 14(3), 431-450. doi:10.1108/JIC-032013-0035

Farr, J., \& Ford, C. (1990). Individual Innovation. In M. West \& J. Farr (Eds.), Innovation and Creativity at Work: Psychological and Organizational Strategies (pp. 63-80). Chichester: Wiley.

Flamholtz, E. G., \& Lacey, J. M. (1981). Flamholtz EG, Lacey JM. Personnel Management, Human Capital Theory, and Human Resource Accounting. Los Angeles: Inst. Ind. Relat., Univ. Calif.

Freeman, C. (1982). The Economics of Industrial Innovation (2nd Editio.). London: Pinter.

Haar, J. M., \& Spell, C. S. (2004). Programme Knowledge and Value of Work-Family Practices and Organizational Commitment. The International Journal of Human Resource Management, 15(1), 1040-1054. 
Hannan, M. T., \& Freeman, H. J. (1977). The Population Ecology of organizations. American Journal of Sociology, 82(1), 929-964.

Harney, B., \& Jordan, C. (2008). Unlocking the Black Box: Line Managers and HRMPerformance in a Call Centre Context. International Journal of Productivity and Performance Management, 57(4), 275-296.

Hawley, A. H. (1968). Human Ecology. In L. S. David (Ed.), International Encyclopedia of Social Sciences (pp. 328-37). New York: Macmillan.

Hayes, A. F. (2013). Model Templates for PROCESS for SPSS and SAS. Retrieved from http://www.afhayes.com

Hornsby, J. S., Kuratko, D. F., \& Zahra, S. (2002). Middle managers' perception of the internal environment for corporate entrepreneurship: assessing a measurement scale. Journal of Business Venturing, 17(3), 253-273.

Isabel, M., \& Perez-Santana, M. P. (2014). Managing innovative work behavior $\square$ : the role of human resource practices. Personnel Review, 43(2), 184-208. doi:10.1108/PR-11-2012-0199

Janssen, O. (2000). Job demands, perceptions of effort-reward fairness and innovative work behaviour. Journal of Occupational and Organizational Psychology, 73(3), 287-302.

Jiang, K., Lepak, D., Hu, J., \& Baer, J. (2012). How does human resource management influence organizational outcomes? A meta-analytic investigation of mediating mechanism. Academy of Management Journal, 55(6), 1264-1294.

Katou, A. A., \& Budhwar, P. S. (2010). Causal relationship between HRM policies and organisational performance $\square$ : Evidence from the Greek manufacturing sector. European Management Journal, 28(1), 25-39. doi:10.1016/j.emj.2009.06.001

Katz, M. B. (1975). Class, Bureaucracy, and Schools: The Illusion of Educational Change in America. New York: Praeger.

Kennedy, J. C. (1995). Empowering Employees Through the Performance Appraisal Process. International Journal of Public Administration, 18(1), 793-811.

Khilji, S. E. (2002). Modes of convergence and divergence $\square$ : an integrative view of multinational practices in Pakistan. The International Journal of Human Resource Management, 13(2), 232-253. doi:10.1080/09585190110102350

Kuratko, D. F., Ireland, R. D., Covin, J. G., \& Hornsby, J. S. (2005). A model of middle level managers' entrepreneurial behavior. Entrepreneurship Theory and Practice, 29(6), 699-716.

Lashley, C. (1999). Employee Empowerment in Services: A Framework For Analysis. Personnel Review, 28(1), 169-191.

Leonard, D., \& Sensiper, S. (1998). The role of tacit knowledge in group innovation. California Management Review, 40(1), 112-132.

Leonard-Barton, D. (1995). Wellsprings of Knowledge: Building and sustaining the sources of innovation. Cambridge: MA: Harvard Business School Press.

Lepak, D. P., Liao, H., Chung, Y., \& Harden, E. E. (2006). A Conceptual review of human resource management systems in strategic human resource management research. In J. J. Martochhio (Ed.), Research in Personnel and Human Resource Management (pp. 217-247). Bingley: Emerald Group Publishing Ltd. 
Lowendahl, B. R., Revang, O., \& Fosstenlokken, S. M. (2001). Knowledge and value creation in professional service firms $\square$ : A framework for analysis. Human Relations, 54(7), 911-931.

Meadows, M., \& Pike, M. (2010). Performance Management for Social Enterprises. System Practice Action Research, 23(1), 127-141. doi:10.1007/s1 1213-009-9149-5

Paauwe, J. (2009). HRM and Performance $\square$ : Achievements, Methodological Issues and Prospects. Journal of Management Studies, 46(1), 129-142.

Paauwe, J., \& Boselie, P. (2005). HRM and Performance: What next? Human Resource Management Journal, 15(4), 68-83.

Parker, S. H., Williams, H. M., \& Turner, N. (2006). Modeling the antecedents of proactive behavior at work. Journal of Applied Psychology, 91(3), 636-652.

Pratt, M. (2009). From the editors: The lack of a boilerplate: Tips on writing up (and rewriting) qualitative research. Academy of Management Journal, 52(1), 856-862.

Purcell, J., Kinnie, N., Hutchinson, S., Rayton, B., \& Swart, J. (2003). Understanding the People and Performance Link: Unlocking the Black Box. London: Open University Press.

Scott, W. R. (1995). Institutions and organizations. Thousand Oaks. CA: Sage.

Shalley, C., Zhou, J., \& Oldham, G. R. (2004). The effects of personal and contextual characteristics on creativity: where should we go from here? Journal of Management, 30(6), 933-958.

Siegall, M., \& Gardner, S. (2000). Contextual Factors of Psychological Empowerment. Pesonnel Review, 29(1), 703-722.

Spender, J. C. (1996). Making knowledge the basis of a dynamic theory of the firm. Strategic Management Journal, 17(Winter Special Issue), 45-62.

Spreitzer, M. G. (1995). Psychological Empowerment in the Workplace: Dimensions, Measurement, and Validation. Academy of Management Journal, 38(5), 1442-1465.

Subramony, M. (2009). A Meta-analytic investigation of the relationship between HRM bundles and firm Performance. Human Resource Management, 48(5), 745-768.

Suddaby, R., Hardy, C., \& Nguyen, H. Q. (2011). Where are the New theories of Organization? Academy of Management Review, 36(2), 236-246.

Sun, L., Aryee, S., \& Law, K. S. (2007). High-Performance human resource practices, citizenship behavior and organizational performance: A relational perspective. Academy of Management Journal, 50(3), 558-577.

Thomas, K. W., \& Velthouse, B. A. (1990). Cognitive Elements of Empowerment: An "interpretive" model of intrinsic task motivation. Academy of Management Review, 15(4), 666-681.

Tsoukas, H. (1996). The firm as a distributed knowledge system: A constructionist approach. Strategic Management Journal, 17(1), 11-25.

Tyack, D. B. (1974). The One Best System. Cambridge Mass: Harvard University Press.

Woodward, J. (1965). Industrial Organization, Theory and Practice. London: Oxford University Press. 